\title{
Influence of the structural framework on peat bog distribution in the tropical highlands of Minas Gerais, Brazil
}

\author{
José Ricardo da Rocha Campos ${ }^{\mathrm{a}}$, Alexandre Christófaro Silva ${ }^{\mathrm{b}}$, Marcos Rafael Nanni ${ }^{\mathrm{c}}$, \\ Marcilene dos Santos ${ }^{\mathrm{d}}$, Pablo Vidal-Torrado ${ }^{\mathrm{e}, *}$ \\ a Agronomy Department, Federal Technological University of Paraná, Pato Branco, PR. CEP, 85501-970, Brazil \\ b Forest Engineering Department. Federal University of Jequitinhonha and Mucuri Valley, Diamantina, MG. CEP, 39100-000, Brazil \\ c Department of Agronomy, The State University of Maringa, Maringá, PR. CEP, 87020-900, Brazil \\ d Department of Geography, São Paulo State University, Ourinhos, SP. CEP, 19910-206, Brazil \\ e Soil Science Department, Luiz de Queiroz College of Agriculture, University of São Paulo, Piracicaba, SP. CEP, 13418-900, Brazil
}

\section{A R T I C L E I N F O}

\section{Keywords:}

Organic matter

Peatlands

Structural and geomorphic conditioning

Water flow

\begin{abstract}
A B S T R A C T
Peat bogs are ecosystems characterized by high levels of organic matter (OM), which accumulates in environments of low biological activity. The peat bogs present in the tropical highlands of Serra do Espinhaço Meridional (SdEM), Brazil, are associated with hydromorphic environments formed under specific conditions and the strong influence of the quartzite basement, whereby a complex pattern of faults, fractures and folds has deeply affected the drainage network and geomorphological framework. This study investigated the influence of the structural framework on the distribution and morphology of these ecosystems within a hydrological and geomorphological context. The physical features of the landscape were analyzed using geological maps, a digital elevation model and by mapping the main geomorphological feature patterns obtained from geographic information systems (GIS). Ground Penetrating Radar transects were taken in representative areas, as the best strategy for detection of buried peat bogs, as well as to analyze bedrock configuration and infer its relationship with water flow. Four peat bog typologies were identified: "entrenched bogs", "subsurface bogs", "structural bogs", and "hanging bogs". The distribution and morphology of these typologies display a strong relationship either with alluvial sediments and floodplains or with structural/lithological features which caused water retention.
\end{abstract}

\section{Introduction}

Peat bogs are ecosystems formed through the accumulation of vegetal remains in environments presenting conditions unfavorable to the activity of decomposing microorganisms (Moore, 1997). Reduction in the energy of water flow is a requisite for bog formation, as this maintains a wet environment favoring the development of hygrophilous vegetation and organic matter $(\mathrm{OM})$ accumulation. In Brazil, the tropical highlands of Serra do Espinhaço Meridional (SdEM) constitute a relevant region for the presence of peat bogs. These highlands consist principally of quartzite rocks and are characterized by a diversity of geomorphic features influenced by lithological and structural aspects.

There is a predominance of sheared and fractured quartzite rock substrate, which has been influential in delineating ridges, cliffs, depressions, deep valleys and alluvial plains aligned to tectonic directions, as well as delineating dissected plateaus and plateau remnants at different topographic levels. These morphologically resis- tant rocks provide structural obstacles preventing free drainage and therefore controlling the distribution and morphology of the peat bogs in the area. In the depressed areas of the landscape and on the valley floors, there are extensive deposits of sandy sediments from the Holocene and Pleistocene, with bogs occurring in certain places (Saadi, 1995; Augustin et al., 2011; Barreto et al., 2013). Given the right conditions, bogs can be found buried beneath sediments of alluvial or colluvial origin, but can be observed in places where erosion ravines expose the peat deposits.

Peat bogs represent an important genetic reservoir of plant and animal species (Silva et al., 2012a, 2012b; Horak-Terra et al., 2014). As these environments are highly sensitive to climatic changes, plant remnants and pollen in the peat bog enable reconstruction of environmental change during the Late Pleistocene - Holocene (Horak-Terra et al., 2014; Zádorová et al., 2015).

As a record of climate change, the peat bogs of the SdEM are of great importance, because the climate of the region is influenced by the South

\footnotetext{
* Corresponding author.

E-mail address: pvidal@usp.br (P. Vidal-Torrado).
} 
American monsoon system and by the convergence zone of the South Atlantic (Horak-Terra et al., 2014). These conditions therefore make the results obtained from the peat bogs of the SdEM highly representative in terms of global climate changes (Horak-Terra et al., 2014; Bispo et al., 2016). The SdEM peat bogs also influence water dynamics and water quality in the region, ensuring sustainability of watercourses and formation of C storages (Comas and Slater, 2007; Campos et al., 2011, 2012).

Although not common in the tropical zone of South America due to high temperatures and seasonal wet periods that promote high rates of organic matter decomposition (Martinez-Cortizas et al., 2002), peat bogs can form at high altitude, on river plains and on wetlands, where climatic conditions and drainage favor the deposition of $\mathrm{OM}$ (Pontevedra-Pombal and Martínez Cortizas, 2004). In the SdEM, peat bogs are formed through the combined influence of the morphology and lithology, but precisely how this works is essentially unclear. It is our purpose to elucidate these factors by analyzing the influence of substrate features on the landforms and their relationship with the distribution and morphology of the peat bogs.

\section{Material and methods}

\subsection{Location and characterization of the study site}

The study area extends for $5200 \mathrm{~km}^{2}$ and consists of Quartzites, Metassiltites, Phyllites, Granites, Migmatites and Metamagmatic rocks (Fig. 1).The climate is mesothermic (cwb on the Köppen classification) with an average annual temperature of $18.7^{\circ} \mathrm{C}$. Winters are cold and dry, while summers are mild and wet. The average annual precipitation is $1500 \mathrm{~mm}$ (Silva et al., 2012a, 2012b).

\subsection{Geomorphology}

The influence of lithological and structural characteristics of the substrate on the landform framework, and its relationship with peat bog distribution and morphology, were analyzed through the elaboration of thematic maps. This analysis aimed to identify relationships between major lithological and structural features of the substrate, different relief compartmentations and peat bog distribution and morphology.

Thus, information on the principal lithological and structural characteristics of the substrate was acquired from geological maps and from mapping of the structural lineaments in the study area.

Information on the types of rock found in the area was obtained through the compilation of geological maps of Rio Vermelho (Tupinambá et al., 1996), Diamantina (Fogaça, 1996), Presidente Kubitschek (Knauer and Fogaça, 1996) and Serro (Knauer and Grossi Sad, 1996), all at a scale of 1:100,000 and provided by CODEMIG Company for the Economic Development of Minas Gerais. The compilation of maps was carried out using the Geographic Information System (GIS), with WGS 1984 23S as the Datum.

To map the geomorphological features and identify areas favorable to peat bog formation, we used images from the SRTM (Shuttle Radar Topography Mission) and Landsat 7. The images were processed in GIS in order to obtain the following products: slope map (Fig. 2b), hypsometric map (Fig. 2a) and relief shading with structural lineaments (Fig. 2c) (Grohmann et al., 2007; Carvalho and Bayer, 2011; Augustin et al., 2011). The drainage network (Fig. 2d) was compiled from maps at a scale of 1:100,000 from CODEMIG.

Structural lineaments were mapped from the drainage network and hypsometric maps by tracing linear segments along drainage anomalies such as straight segments, linear valleys, elbows, alignments of confluence points and sub-catchment asymmetries. The delineation of prominent straight escarpments and linear ridges was carried out using the same method (Roldan et al., 2010; Couto et al., 2011). Several lineaments were checked in the field in order to verify the reliability of the results.

Features considered as similar were grouped together based on morphosculptural characteristics (shapes resulting from water action and denudation processes) and morphostructural framework (relief shapes associated with tectonic and stratigraphic aspects) and classified according to Pavlopoulos et al. (2009) and Augustin et al. (2011). Special attention was given to flat environments, such as valley floors, which represent potential locations for the occurrence of peat bogs.

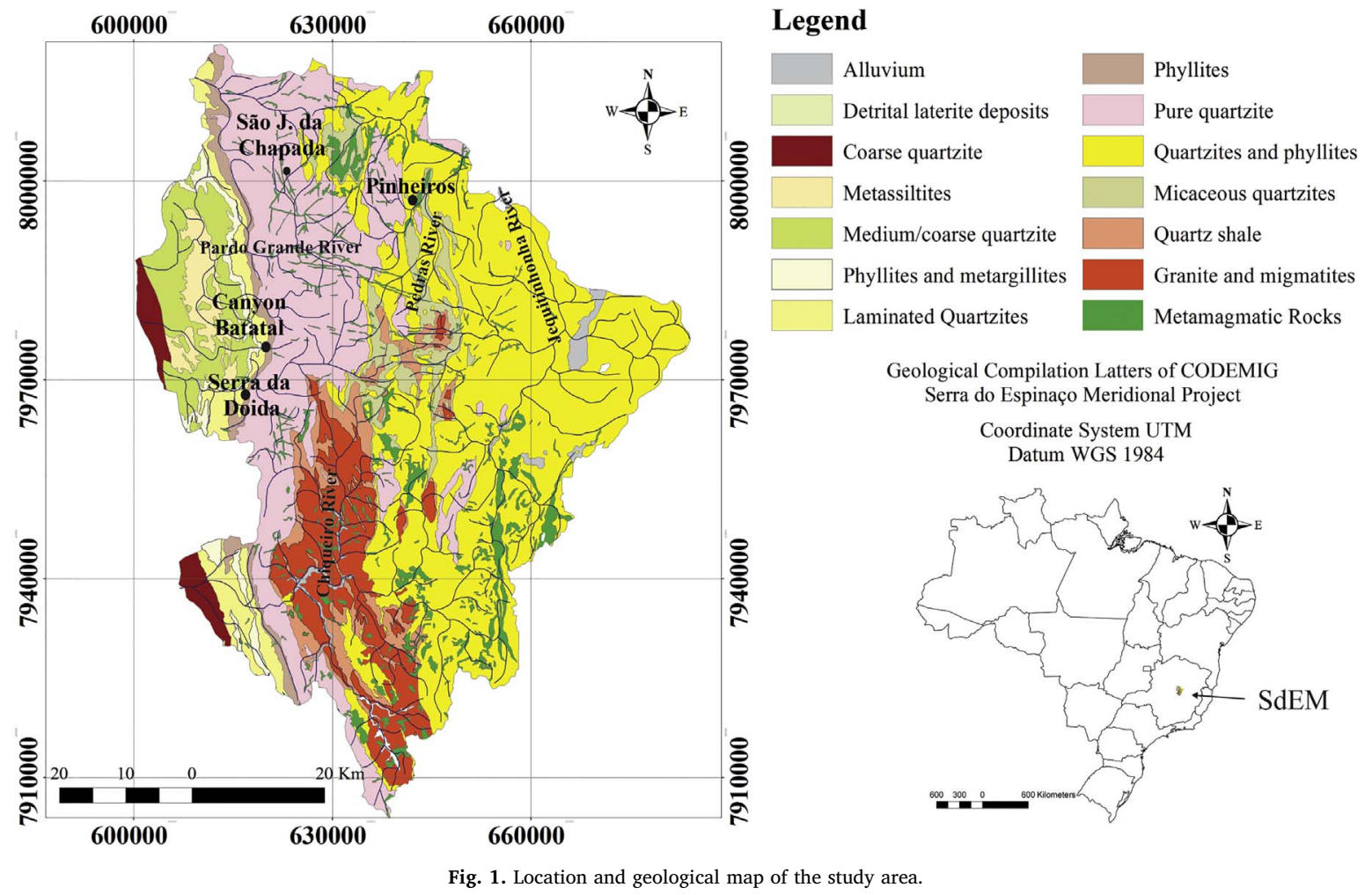




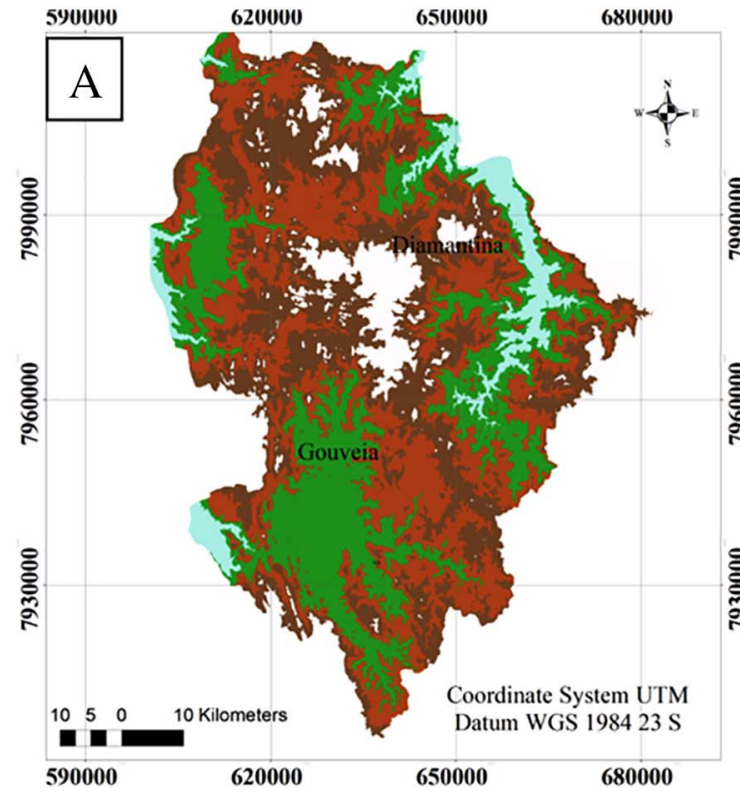

Legend

Hypsometric map

Elevation (m)

$565-912$

$912-1.070$

$1.070-1.189$

$1.189-1.320$

$1.320-2.045$

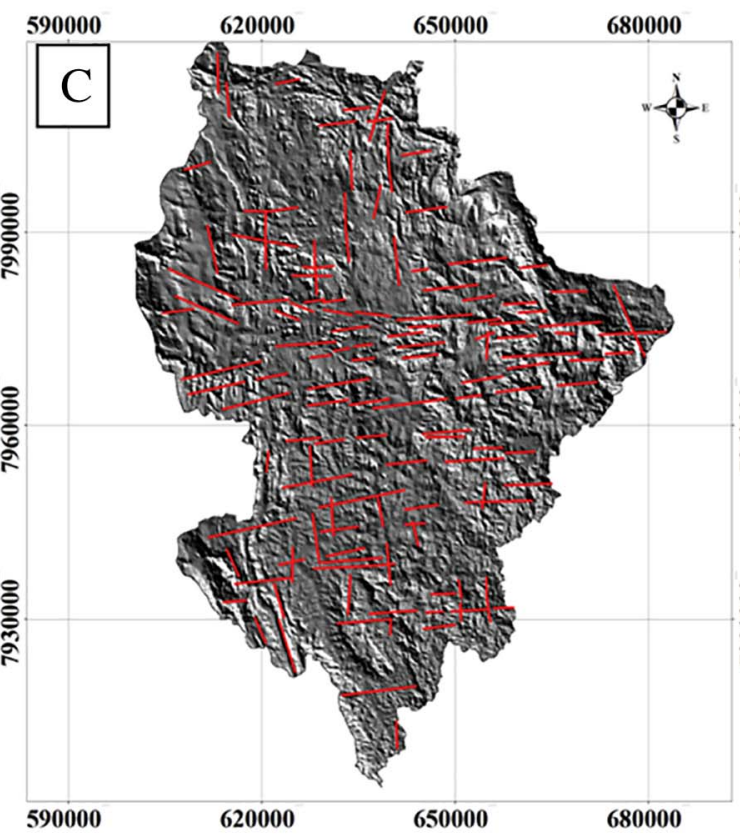

Legend

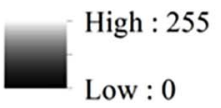

20

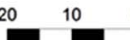

Low : 0

- Structural Lineaments

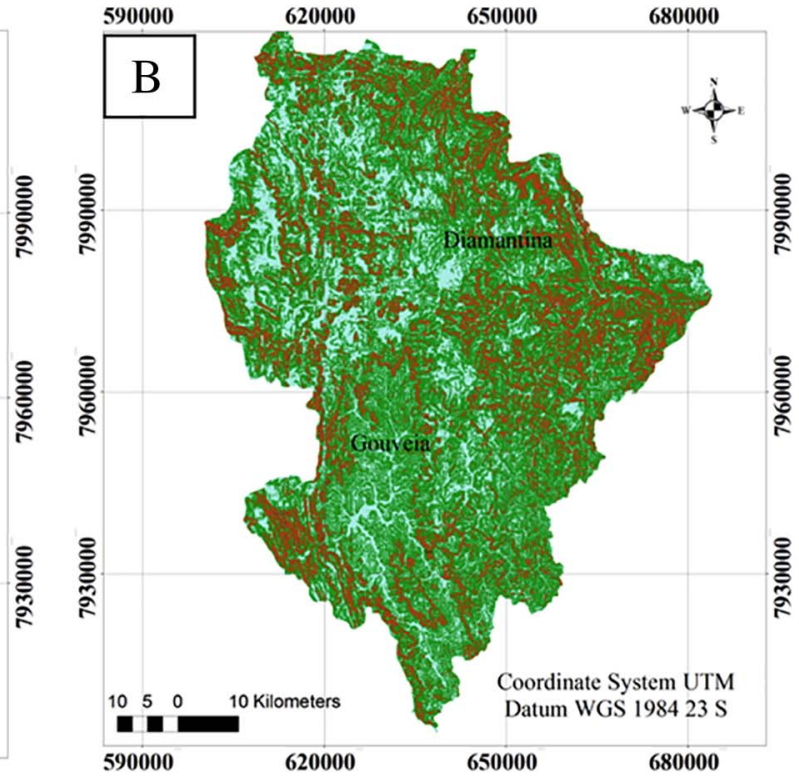

Legend

Slope (\%)

0 - $3=10-25 \square 45-100$

$=3-10=25-45$

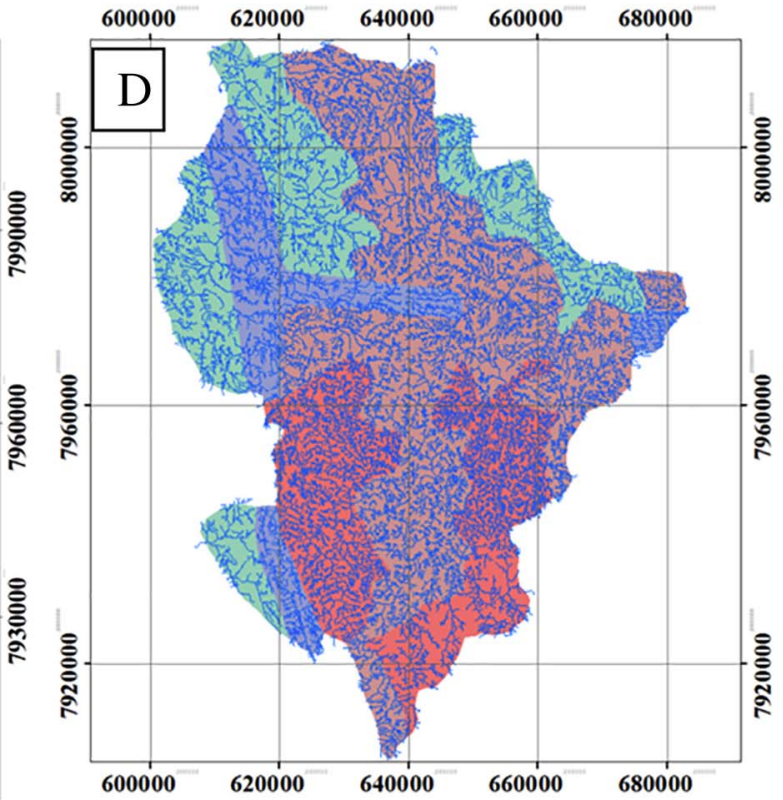

Legend Drainage patterns

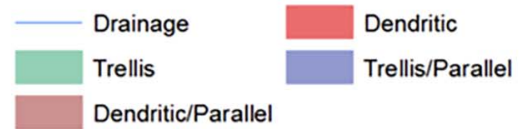

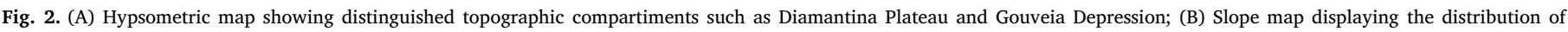

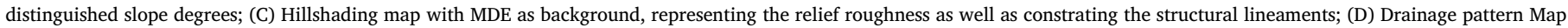
showing the compartments of distinguished drainage patterns in the study area. 


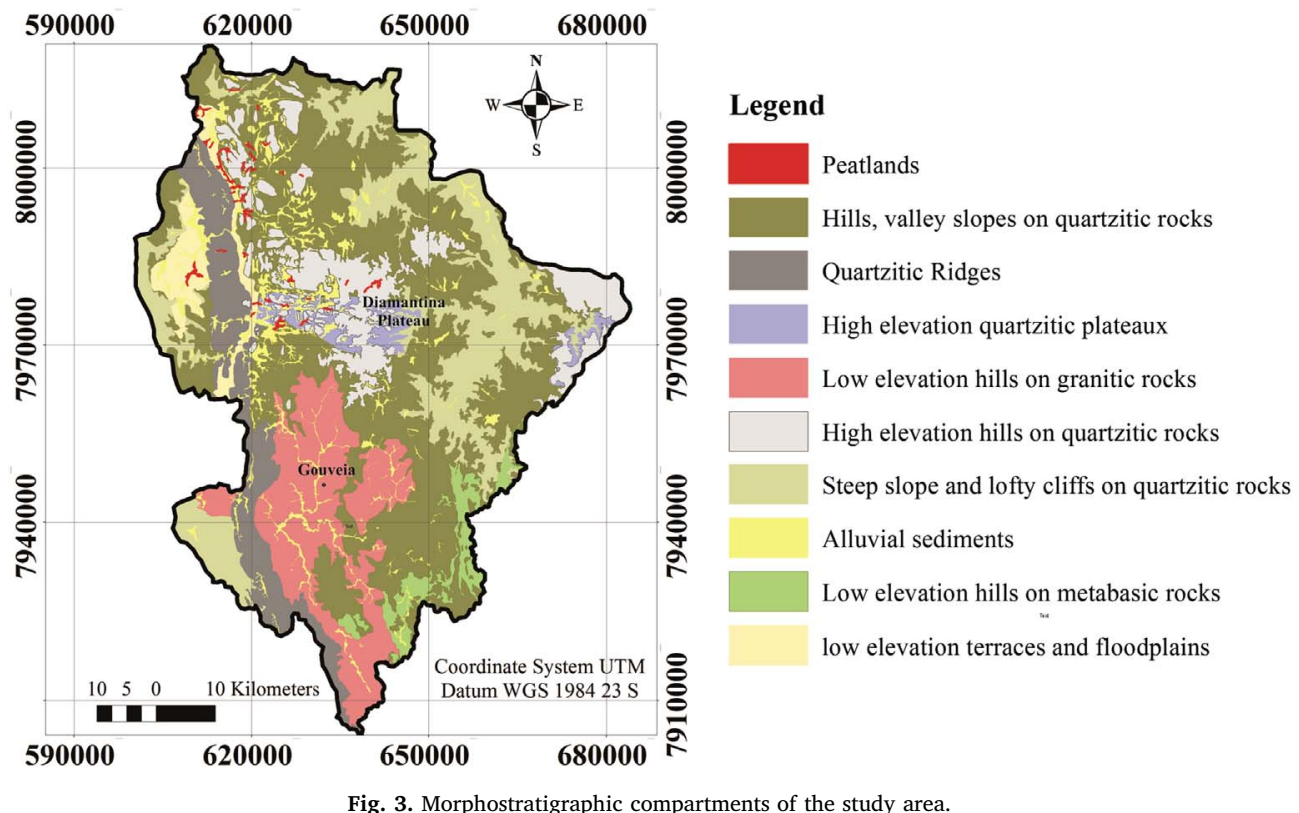

\subsection{Areas selected for description}

Based on analysis of the maps generated in the previous steps, field work studies were then carried out in order to verify peat bog distribution, as well as to identify and analyze different morphologies. Field work results enabled selection of four areas representative of the different types of peat bog observed in the SdEM: 1 - São João da Chapada region: peat bog in a Hanging Valley; 2 - Pinheiros region: peat bog in an area where the drainage is adapted to a geological fault and is under the influence of different rock types; 3 - Serra da Doida region: peat bog in a flat area formed by sediments of alluvial and colluvial origin; 4 - Canyon Batatal region: peat bog in a flat valley embedded between quartzites. These areas were subjected to a detailed analysis of their morphology from a geomorphic perspective.

A morphostratigraphic compartments map was elaborated based on integrated analysis of thematic maps and field work studies. The map displays different relief compartments and the distribution of alluvial sediments, terraces and floodplains and peatlands.

\subsection{Ground penetrating radar (GPR) analysis}

Four areas representative of the different environments for peat bog formation were selected, based on the cartographic material described above and observations in the field. These represented valley bottoms with flat relief over quartzite rocks. In the field, when sandy sediments are observed on the surface rather than peat bog, transects were delineated to use Ground Penetrating Radar (GPR). GPR was then used to identify subsurface peat bogs and the presence of rocky structures impeding water flow in the subsurface. Identification of said structures was carried out through interpretation of contrasts and different texture patterns on the radargrams generated by the aforementioned equipment (Comas and Slater, 2007; Jol, 2008).

A Malã device with $250 \mathrm{MHz}$ shielded antenna and $0.1 \mathrm{~m}$ of trace spacing was used. This was defined based on field tests with 250 and $500 \mathrm{MHz}$ antennas, whereby the latter did not present satisfactory results.

Data processing was carried out using ReflexW software and the following treatments were applied: 1) Static correction enabling suppression of multiple reflections from the surface and data preparation for subsequent procedures. 2) Dewow: GPR data often shows low frequency content, however with this filter, a running mean value is calculated for each value of each trace, which is subtracted from the central point, improving image quality. 3) Gain function: used to highlight important information in deeper layers (Comas et al., 2005; Comas and Slater, 2007; Jol, 2008).

Probes were made using $2.0 \mathrm{~m}$ iron rods in order to verify real depth in comparison to depth observed on the radargrams and make any necessary modifications.

\section{Results and discussion}

\subsection{Relief partitioning}

The arrangement of geomorphological units is segmented in the central portion of the area by a range of structural lineaments in an E-W direction (Fig. 2c). This arrangement determines and controls part of the Quaternary alluvial sedimentation, which then follows the same direction.

On the Diamantina Plateau (Fig. 3), the High Elevation Quartzite Plateau geomorphological unit represents the residual relief, which is composed of flat to slightly convex tops of quartzite lithology. Peat bogs were not observed in this unit, which is probably due to a lack of locations suitable for the accumulation of humidity.

Also located in the highest section, the High Elevation Hills on Quartzite Rocks unit is deeply fractured with frequent quartzite rock outcrops and structural lineaments in an E-W direction. Drainage directions, such as elbows and straight segments, are associated with these lineaments (Augustin et al., 2011; Barreto et al., 2013). As observed on the High Elevation Quartzite Plateau unit, neither peat bogs nor hydromorphic environments were observed within the present unit.

The Quartzite Ridges unit (Fig. 3) is positioned perpendicular to the aforementioned lineaments. It consists of mainly pure fine quartzites, extending from the far south to the extreme north of the study area (Knauer, 2007; Santos et al., 2015). These structures occur frequently in the western compartment of the study area and may be related to the compressive genesis of the Espinhaço Mountains (Almeida-Abreu, 1995). The landforms resulting from geomorphic processes on this substrate consist mainly of ridges, escarpments, anticlines and deep valleys adapted to tectonic trends.

The positioning of the Quartzite Ridges unit, associated with denudation processes on upper areas, enabled the formation of the Alluvial Sediments unit (Fig. 3), which is composed mainly of Quaternary sandy sediments. In certain areas, peat bogs formed in preterite 


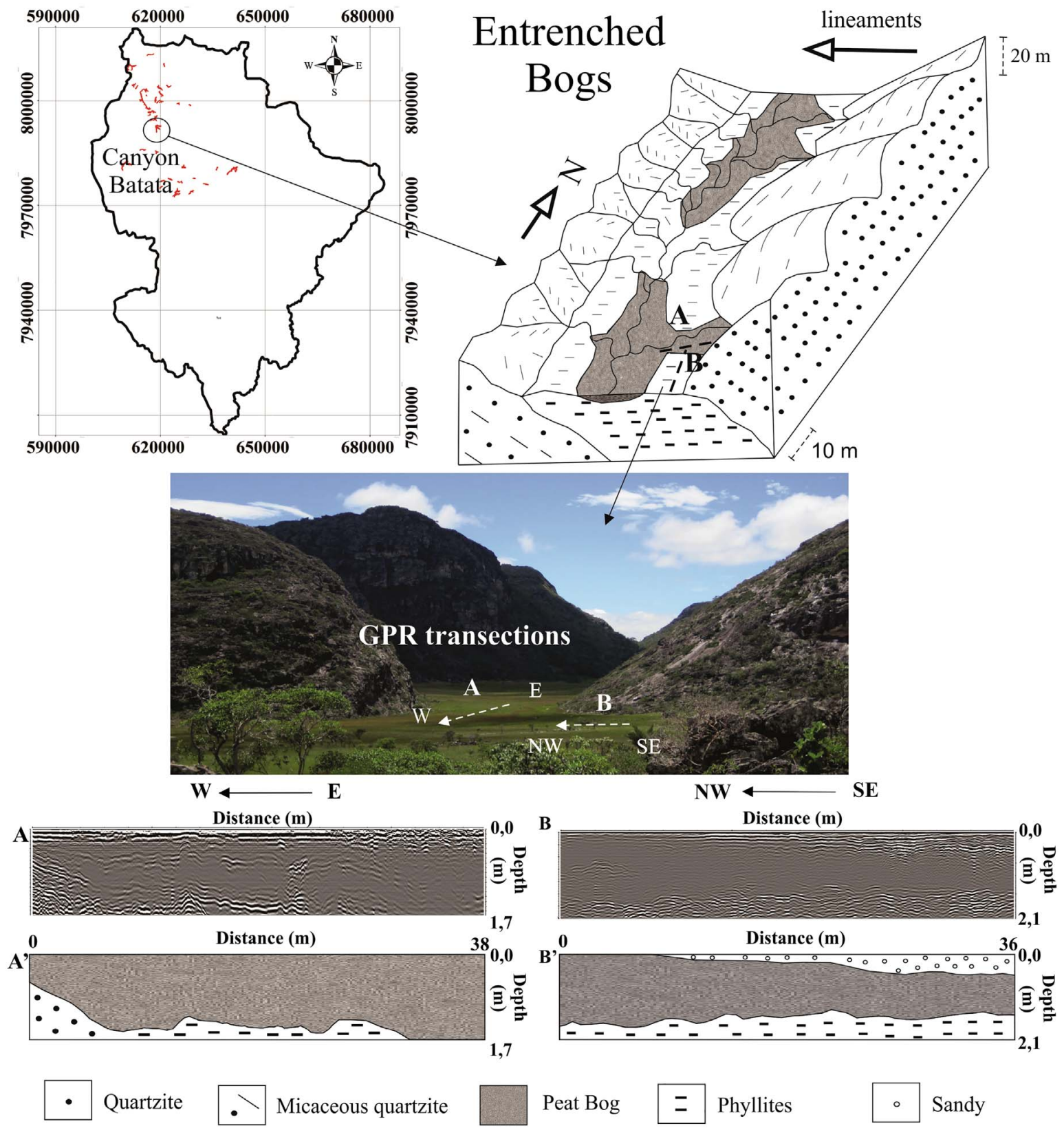

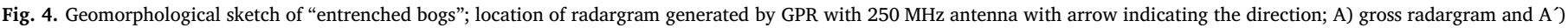
radargram interpretation.

periods can be found buried by sandy sediments. These peat bogs can be seen in places where there is evidence of erosion of the overlying sandy layer exposing the preterite organic deposit.

Confined between the Quartzite Ridges and High Elevation Hills on Quartzite Rocks (Fig. 4), there is a narrow strip of phyllite rock, which is associated with the Very Low Elevation Terraces and Floodplains unit (Santos et al., 2015). The susceptibility of phyllites to weathering has caused slightly undulating relief, characterized by gentle landforms such as discrete hills with convex tops and slopes ranging from straight to slightly concave. Hydromorphism and peat bogs are common where there is contact between this unit and the Quartzite Ridges unit, as a result of water stagnation on the floodplains.

The Hills and Valley Slopes on Quartzite Rocks unit (Fig. 3) resulted from the combination of lithotypes with different susceptibilities to weathering, such as quartzites, meta-gravels, micaceous quartzites and shale, and also as a result of the high variability of tectonic structures (Knauer, 2007; Silva, 2005). This complex geological structure causes knickpoints which prevent free drainage, resulting in hydromorphic environments with favorable conditions for peat bog formation.

The Low Elevation Hills on Granitic Rocks unit is located around the Gouveia municipality and consists of a depression in the quartzite massif of the SdEM surrounded by escarpments (Salgado and Valadão, 2003). This formation features convex and polyconvex hills (Fig. 3) carved into granites, gneisses and migmatites of the Gouveia Complex (Rezende et al., 2010; Barreto et al., 2013). Drainage is mainly dendritic and the lack of structures preventing free drainage makes permanently hydromorphic environments less common. Peat bogs were not found in this unit.

The Steep Slope and Lofty Cliffs on Quartzite Rocks unit (Fig. 3) is formed on quartzite. Slopes can reach values higher than $75 \%$, rocky outcrops are frequent and underdeveloped soils are widespread. In this unit, the high energy of the water flow, caused by the steep slopes, impedes the formation of hydromorphic environments and of peat bogs.

The Low Elevation Hills on Metabasic Rocks unit (Fig. 3) is located 

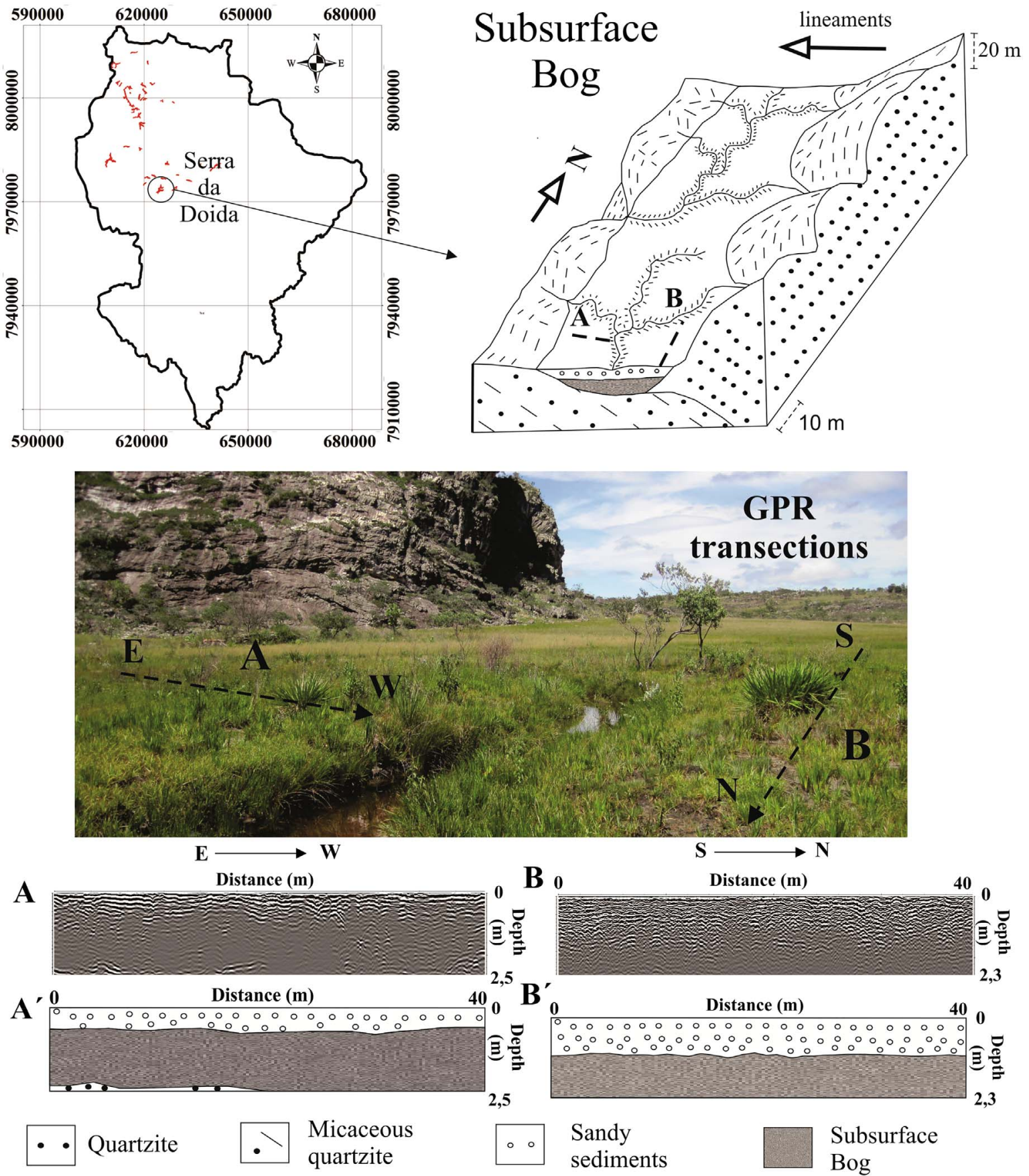

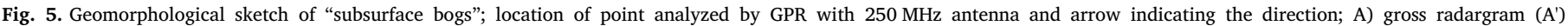
interpretation of radargram with details of the abrupt contact between the sand layer and subsurface peat bog.

in the far southeastern portion of the study area and is found mainly on metabasic rocks (Almeida-Abreu et al., 2005). Clayey fertile soils with high levels of iron oxides sustain lush vegetation on a landscape that features hills with convex tops. This landscape does not favor peat bog formation.

\subsection{Peat bog formation environments}

In general, peat bog formation is associated with factors that prevent free drainage. Four types of peat bog were observed: "entrenched bogs" (bogs entrenched between quartzite rock outcrops), "subsurface bogs" (bogs buried by sandy sediments), "structural bogs" (bogs formed by water stagnation at the limit of a strata of rocks positioned perpendicular to drainage direction) and "hanging bogs" (bogs formed by water stagnation along hanging valleys in quartzite terrain).

In the mapped area, around 55\% of the peat bogs are associated with flat hydromorphic areas formed over phyllites and confined between quartzite rocks. These are classified as "entrenched bogs" (Fig. 4). The E-W direction drainage from the upper portions of the landscape reconfigures and starts to flow $\mathrm{N}-\mathrm{S}$, adapted to the direction of the Quartzite Ridges. In this process, water flow energy decreases, causing water stagnation and formation of hydromorphic environments.

GPR studies show that the referred peat bog is in direct contact with the quartzite/phyllite basement, which controls the water flow and maintains the bog embedded between the surrounding outcrops. On the radargrams there was no sign of any subsurface faults or fractures 


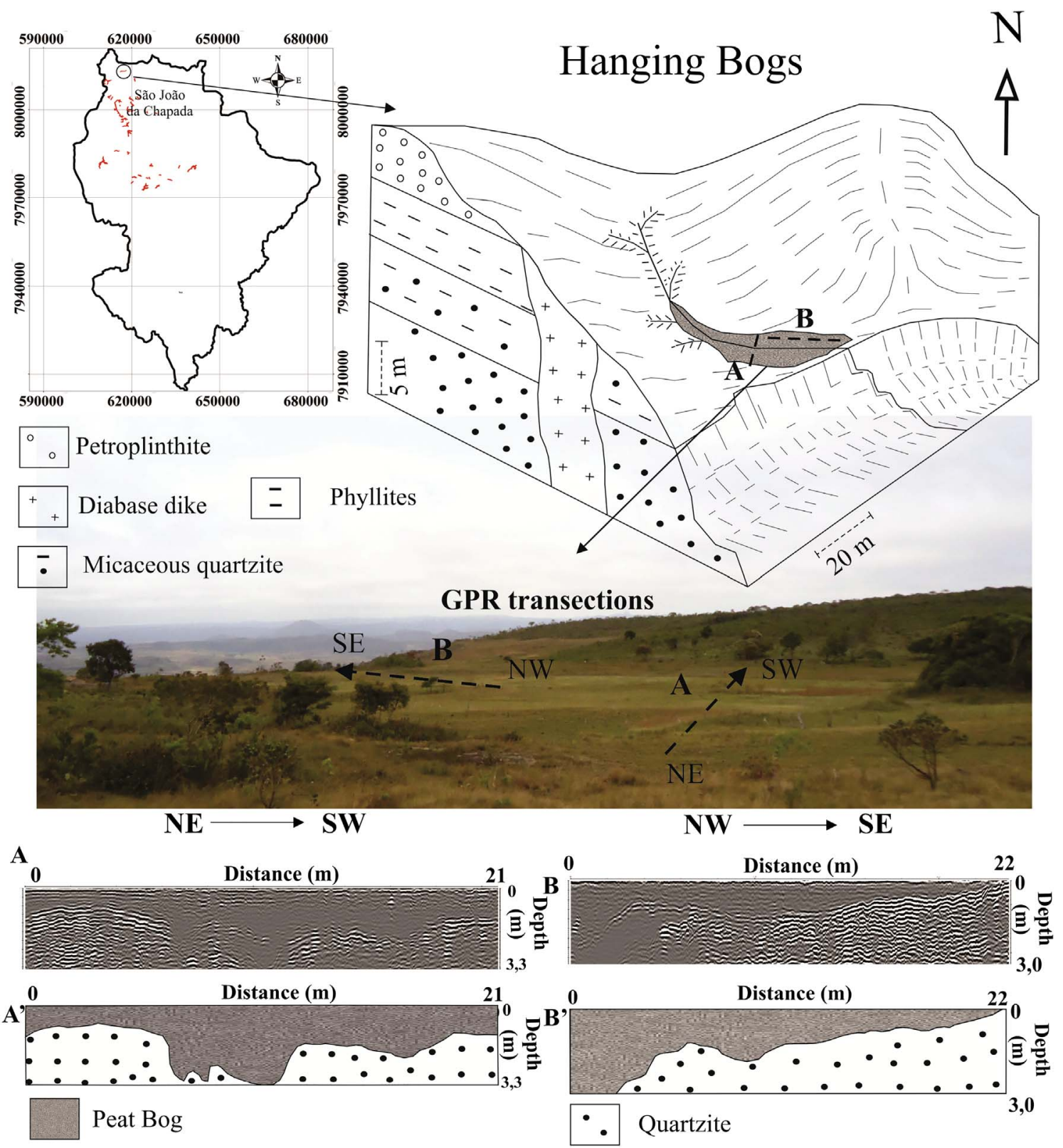

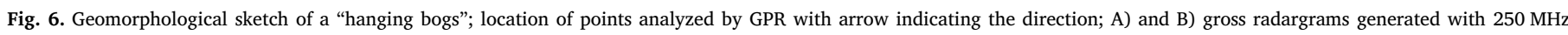
antenna and their interpretations to A') and B') showing the close contact between the peat bog and the rocky bedrock.

enabling water flow to deeper layers.

"Buried bogs" are formed under circumstances similar to those of "entrenched bogs". The genesis of flat valley floors is caused by the deposition of Quaternary sandy sediments that buried peat bogs at specific points (Fig. 5). These peat bogs may have been buried by deeper erosive processes occurring during periods marked by drier weather, as observed by Horak-Terra et al. (2014) in the peat bog of Pau-de-Fruta (SdEM), and by Campos et al. (2016) in the peat bog of Serra da Doida (SdEM).

GPR radargrams show 3 distinct stratigraphic layers: sand, peat bog and a layer of rock in direct contact with the peat bog layer (Fig. 5A). It can also be observed in the radargrams that peat deposits generally occur in layers close to the surface, varying from $20 \mathrm{~cm}$ up to $1.5 \mathrm{~m}$ in depth.

Approximately $30 \%$ of the mapped peat bogs occur in the Hills and Valley Slopes on Quartzite Rocks unit. The formation of these peat bogs is mainly associated with tectonic structures and quartzite hardness, which prevent the formation of new drainage channels and favor locations with permanent hydromorphism. Two types of peat bog were observed in this unit: "hanging bogs" and "structural bogs".

Subsurface details such as contact between the peat bog and the basement, as observed in Fig. 6, show that the peat bog area is confined to its low position by a quartzite structure partially preventing free drainage. This structure occurs due to a perpendicular fault that segments the relief, maintaining the upstream environment lentic and hydromorphic, while the downstream environment is lotic with high energy.

Peat bogs found in the Hills and Valley Slopes on Quartzite Rocks unit, were "structural bogs". In this case, the main drainage presents a rectilinear aspect due to its adaptation to a SW-NE sub-vertical strikeslip fault (Fig. 7). Subsurface details on the radargram (Fig. 7) show that spatial configuration of drainage in relation to bedding causes the formation of discrete knickpoints, which reduce the energy flow and maintain the upstream environment hydromorphic. Small downstream waterfalls with staggered gaps ranging from 30 to $50 \mathrm{~cm}$ were also observed. 

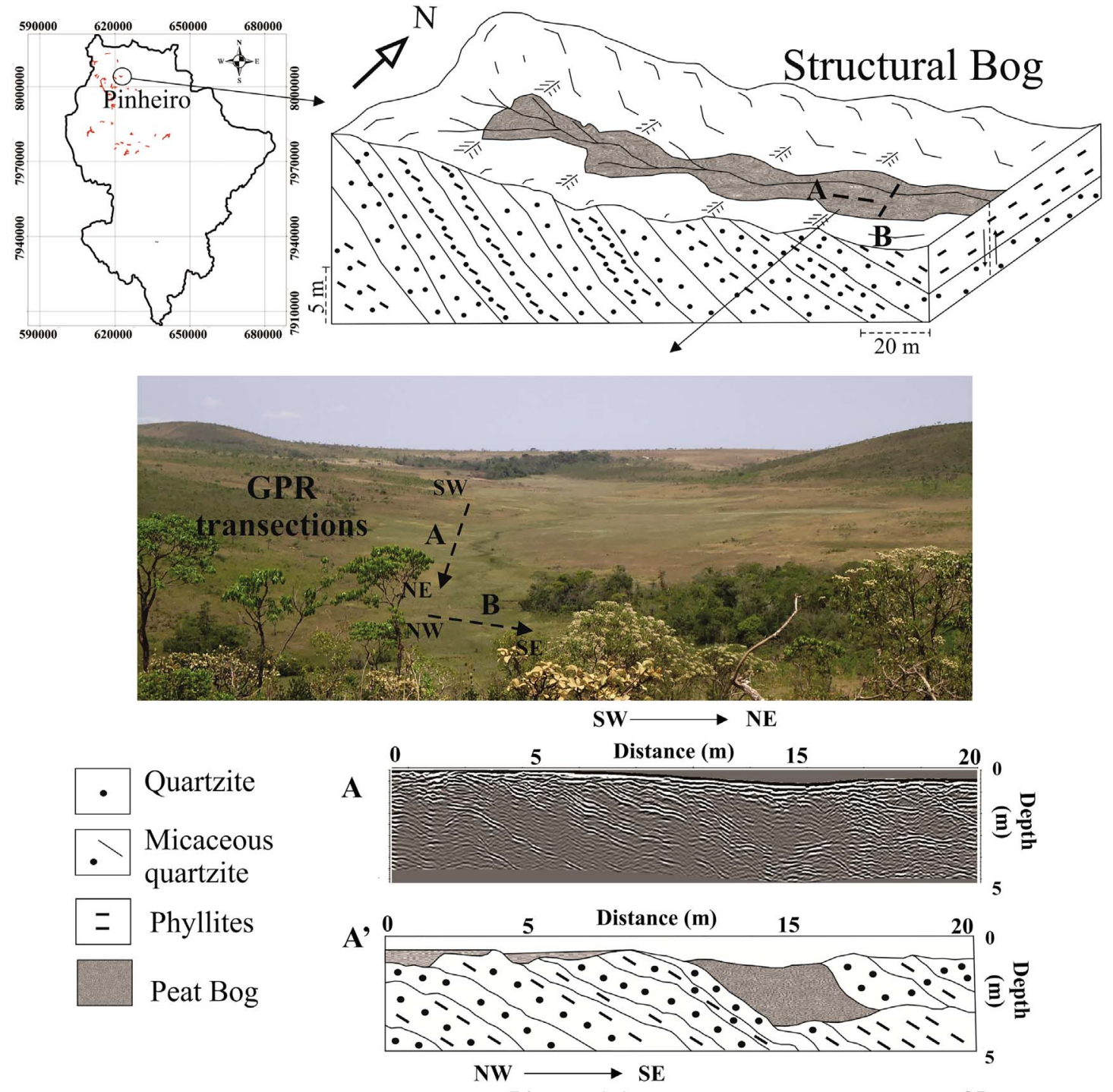

B 0

Distance (m) 25

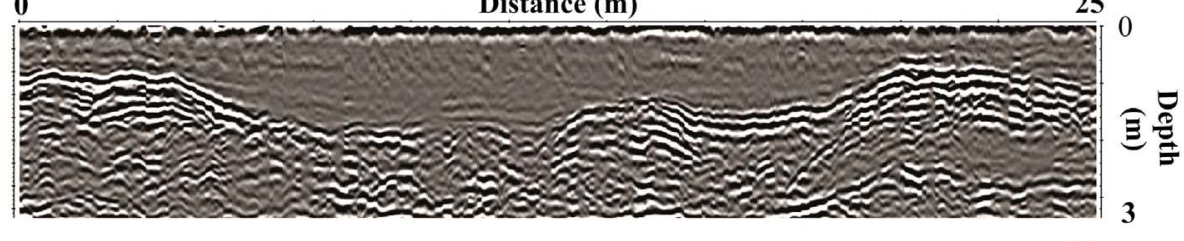

B

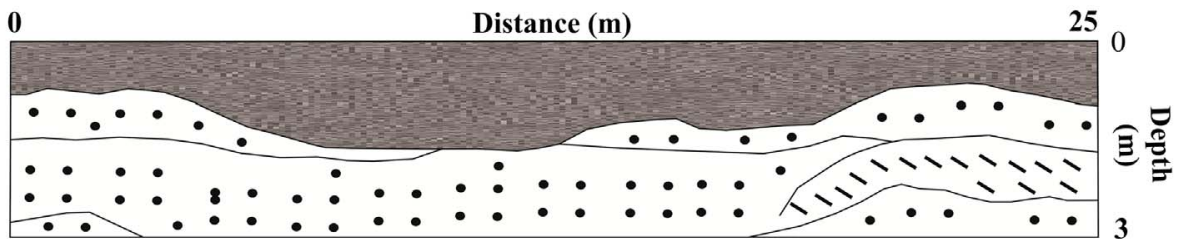

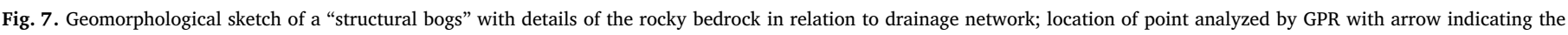
direction; (A) gross radargram generated with $250 \mathrm{MHz}$ antenna and (A') interpretation of the abovementioned radargram with detail of rock bedding.

\section{Conclusion}

The formation of four types of peat bogs ("entrenched bogs", "subsurface bogs", "structural bogs" and "hanging bogs") is influenced by the structural framework and the denudation dynamics of the quartzite landscape in the SdEM, as well as by aggradation landforms associated with Quaternary alluvial sedimentation along valley floors. For the four types of peat bog, quartzite structures were observed retaining water flow, conditioning drainage and maintaining the environment permanently hydromorphic.

The results suggest that peat bog formation in the SdEM is related not only to climate conditions, but also to the hydromorphic environment provided by the relationship between the lithology and morphology of the relief.

The area occupied by the Alluvial Sediments unit is 32,500 ha. This means that the number of peat bogs and the amount of stored carbon may be considerably higher than is presently known. 


\section{Acknowledgments}

The authors wish to thank the São Paulo Research Foundation FAPESP Project 2011/21191-3 and the National Council of Technological and Scientific Development- CNPq Project 482815/ 2011-6 and 304741/2013-2 for financial support and grant to the corresponding author respectively.

\section{A. Supplementary data}

Supplementary data associated with this article can be found in the online version, at doi:http://dx.doi.org/10.1016/j.catena.2017.04.018. These data include the Google map of the most important areas described in this article.

\section{References}

Almeida-Abreu, P.A., 1995. O Supergrupo Espinhaço da Serra do Espinhaço Meridional (Minas Gerais): o rifte, a bacia e o orógeno. Geonomos 3, 1-18.

Almeida-Abreu, P.A., Fraga, L.M.S., NEVES, S.C., 2005. Geologia. In: Silva, A.C., Predreira, L.C.V.S., Almeida-Abreu, P.A. (Eds.), Serra do Espinhaço Meridional: paisagem e ambiente. O Lutador, Belo Horizonte, pp. 19-42.

Augustin, C.H.R.R., Fonseca, B.M., Rocha, L.C., 2011. Geomorphological mapping of Espinhaço Meridional Mountain range: first approximation. R. Geonomos 19, 50-69.

Barreto, H.N., Varajão, C.A.C., Brauches, R., Bouries, D.L., Salgado, A.A.R., Varajão, A.F.D.C., 2013. Denudation rates of the southern Espinhaço range, Minas Gerais, Brazil, determined by in situ-produced cosmogenic beryllium-10. Geomorphology 191, 1-13.

Bispo, D.F.A., Silva, A.C., Silva, M.L.N., Barbosa, M.S., Silva, B.P.C., Barral, U.M., Fabris, J.D., 2016. Hydrology and carbon dynamics of tropical peatlands from Southeast Brazil. Catena 143, 18-25.

Campos, J.R.R., Silva, A.C., Fernandes, J.S.C., Ferreira, M.M., Silva, D.V., 2011. Water retention in a peatland with organic matter in different decomposition stages. R. Bras. Ci. Solo 35, 1217-1227.

Campos, J.R.R., Campos, J.R.R., Silva, A.C., Vidal-Torrado, P., 2012. Mapping, organic matter mass and water volume of a peatland in Serra do Espinhaço meridional. R. Bras. Ci. Solo 36, 723-732.

Campos, J.R.R., Silva, A.C., Slater, L., Nanni, M.R., Vidal-Torrado, P., 2016. Stratigraphic control and chronology of peat bog deposition in the Serra do Espinhaço Meridional, Brazil. Catena 143, 167-173.

Carvalho, T.M.D., Bayer, M., 2011. Utilização dos Produtos da "Shuttle Radar TopographyMission"(SRTM) no Mapeamento Geomorfológico do Estado de Goiás. R. Bras. Geomorfol. 9, 35-41.

Comas, X., Slater, L., 2007. Evolution of biogenic gases in peat blocks inferred from noninvasive dielectric permittivity measurements. Water Resour. Res. 43, 1-10.

Comas, X., Slater, L., Reeve, A., 2005. Stratigraphic controls on pool formation in a domed bog inferred from ground penetrating radar (GPR). J.Hydrol. 315, 40-51.

Couto, E.V., Manieri, D.D., Manosso, F.C., Fortes, E., 2011. Correlação morfoestrutural da rede de drenagem e lineamentos da borda planáltica, Faxinal, Paraná. Geociências 30, 315-326.
Fogaça, A.C.C., 1996. Mapa Geológico da Folha Diamantina. COMIG/UFMG, Belo Horizonte (Escala: 1:100.000).

Grohmann, C.H., Riccomini, C., Alves, F.M., 2007. SRTM - based morphotectonic analysis of the Poços de Caldas Alkaline Massif, southeastern Brazil. Comput. Geosci. 33, 10-19.

Horak-Terra, I., Martinez Cortizas, A., Camargo, P.B., Silva, A.C., Vidal-Torrado, P., 2014. Characterization of properties and main processes related to the genesis and evolution of tropical mountain mires from Serra do EspinhaçoMeridional, Minas Gerais, Brazil. Geoderma 232, 183-197.

Jol, H.M., 2008. Ground Penetrating Radar Theory and Applications, 1 ed. Elsevier, Amsterdam.

Knauer, L.G., 2007. O Supergrupo Espinhaço em Minas Gerais: considerações sobre sua estratigrafia e seu arranjo estrutural. R. Geonomos 15, 81-90.

Knauer, L.G., Fogaça, A.C.C., 1996. Mapa Geológico da Folha Presidente Kubitschek. COMIG/UFMG, Belo Horizonte (Escala 1:100.000).

Knauer, L.G., Grossi Sad, J.H., 1996. Mapa Geológico da Folha Serro. COMIG/UFMG, Belo Horizonte (Escala: 1:100.000)

Moore, D.P., 1997. Bog standards in Minnesota. Nature 386, 655-657.

Pavlopoulos, K., Evelpidou, N., Vassilopoulos, A., 2009. Mapping Geomorphological Environments, 1 ed. Springer, New York.

Pontevedra-Pombal, X., Martínez Cortizas, A., 2004. Turberas de Galicia: processos formativos, distribuición y valor medioambiental. El caso particular de las"Serras Septentrionais". Chioglossa 2, 103-121.

Rezende, E.A., Leão, M.R., Salgado, A.A.R., Oliveira, C.K.R., Nalini Júnior, A., 2010. A influência litológica nas taxas de denudação geoquímica do médio espinhaço meridional - MG. Soc. Nat. 22, 503-514.

Roldan, L.F., Machado, R., Steiner, S.S., Warren, L.V., 2010. Análise de lineamentos estruturais no Domo de Lages (SC) com uso de imagens de satélite e mapas de relevo sombreado. Geol. USP: Série Cient. 10, 57-72.

Saadi, A.A., 1995. Geomorfologia da Serra do Espinhaço em Minas Gerais e de suas margens. R. Geonomos 3, 41-63.

Salgado, A.A.R., Valadão, R.C., 2003. Contribuição da Denudação Geoquímica na Evolução da Erosão Diferencial no Espinhaço Meridional-MG. R. Bras. Geomorfol. 4, $31-40$.

Santos, M.N., Chemale Jr., F., Dussin, I.A., Martins, M.S., Queiroga, G., Pinto, R.T.R., Santos, A.N., Armstrong, R., 2015. Provenance and paleogeographic reconstruction of a mesoproterozoicintracratonic sag basin (upper Espinhaço Basin, Brazil). Sediment. Geol 318, 40-57.

Silva, A.C., 2005. Solos. In: Silva, A.C., Predreira, L.C.V.S., Almeida-Abreu, P.C. (Eds.), Serra do Espinhaço Meridional: paisagem e ambiente. Belo Horizonte, O Lutador, pp. 59-77.

Silva, V.E., Silva, A.C., Pereira, R.C., Camargo, P.B., Silva, B.C., Barral, U.M., Mendonç Filho, C.V., 2012a. Lignocellulosic and isotopic composition of vegetation and soil organic matter of a tropical peat: I floristic composition, biomass and carbon stock. R. Bras. Ci. Solo 37, 121-133.

Silva, A.C., Silva, V.E., Silva, B.P.C., Camargo, P.B., Pereira, R.C., Barral, U.M., Botelho, A.M.M., Vidal Torrado, P., 2012b. Lignocellulosic and isotopic composition of vegetation and soil organic matter of a tropical peat. II humic substances and humification processes. R. Bras. Ci. Solo 37, 134-144.

Tupinambá, M., Baars, F.J., Uhlein, A., Grossi Sad, J.H., Knauer, L.G., 1996. Mapa Geológico da Folha Rio Vermelho. COMIG/UFMG, Belo Horizonte (Escala: $1: 100.000)$.

Zádorová, T., Penízek, V., Vasát, R., Zizala, D., Chuman, T., Vanek, A., 2015. Colluvial soils as a soil organic carbon pool in different soil regions. Geoderma 253, 122-134. 